\title{
Frailty syndrome in the elderly: conceptual analysis according to Walker and Avant
}

\author{
Síndrome do idoso frágil: análise conceitual de acordo com Walker e Avant \\ Síndrome del anciano frágil: análisis conceptual según Walker y Avant
}

Fabiana Maria Rodrigues Lopes de Oliveira' ORCID: 0000-0002-2985-7572

Keylla Talitha Fernandes Barbosa ' ORCID: 0000-0001-6399-002X

Mayara Muniz Peixoto Rodrigues" ORCID: 0000-0002-0578-8146

Maria das Graças Melo Fernandes" ORCID: 0000-0001-6294-9930

'Centro Universitário de João Pessoa. João Pessoa, Paraíba, Brazil. "Universidade Federal da Paraíba. João Pessoa, Paraíba, Brazil.

How to cite this article: Oliveira FMRL, Barbosa KTF, Rodrigues MMP, Fernandes MGM. Frailty syndrome in the elderly: conceptual analysis according to Walker and Avant.

Rev Bras Enferm. 2020;73(Suppl 3):e20190601. doi: http://dx.doi.org/10.1590/0034-7167-2019-0601

\section{Corresponding author:}

Fabiana Maria Rodrigues Lopes de Oliveira E-mail: fabianarodriguesenf@yahoo.com.br

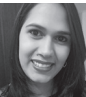

EDITOR IN CHIEF: Antonio José de Almeida Filho ASSOCIATE EDITOR: Ana Fátima Fernandes

Submission: $01-08-2020$

Approval: 03-13-2020

\section{ABSTRACT}

Objective: To analyze the concept of "frailty syndrome" in the literature, according to the method proposed by Walker and Avant. Methods: It is a concept analysis, guided by the method proposed by Walker and Avant, made operational through an integrative literature review. The search in a scientific database was carried out using the descriptors: Frail elderly, syndrome, phenotype, geriatric assessment, and aging. The literary corpus comprised 66 studies. Results: The study found the antecedents and attributes (categorized as physical, sociodemographic, and behavioral/environmental) that integrate the signs and symptoms evidenced in the "frailty syndrome," as well as the consequences of this concept. The variables were analyzed with emphasis on the conceptions that influence the frailty process of the elderly. Conclusion: The study demonstrated the complexity arising from the multifactorial genesis of the referred syndrome, emphasizing the specificities of the elderly's frailty. However, we recommend conducting further research involving the phenomenon in question to understand the construct better.

Descriptors: Nursing; Frail Elderly; Syndrome; Aging; Concept Formation.

\section{RESUMO}

Objetivo: Analisar o conceito "síndrome do idoso frágil", na literatura, de acordo com o método proposto por Walker e Avant. Métodos: Trata-se de uma análise de conceito, orientada pelo método proposto por Walker e Avant, operacionalizada mediante revisão integrativa da literatura. A busca em base de dados científicos foi efetivada utilizando-se os descritores: Frail elderly, syndrome, phenotype, geriatric assessment e aging. Para compor o corpus literário, foram elencados 66 estudos. Resultados: Constataram-se os antecedentes e atributos (categorizados em físicos, sociodemográficos, e comportamentais/ambientais) que integram os sinais e sintomas evidenciados na "síndrome do idoso frágil", bem como os consequentes do referido conceito. Procedeu-se à análise das variáveis com destaque para as concepções que influenciam o processo de fragilização do idoso. Conclusão: $\mathrm{O}$ estudo demonstrou a complexidade proveniente da gênese multifatorial da referida síndrome, ressaltando as especificidades da fragilidade do idoso. Contudo, recomenda-se a realização de novas pesquisas envolvendo o fenômeno em questão para melhor compreensão do constructo.

Descritores: Enfermagem; Idoso Fragilizado; Síndrome; Envelhecimento; Formação de Conceito.

\section{RESUMEN}

Objetivo: Analizar el concepto "síndrome del anciano frágil", en la literatura, según el método propuesto por Walker y Avant. Métodos: Se trata de un análisis de concepto, orientada por el método propuesto por Walker y Avant, es operacionada mediante revisión integrativa de la literatura. La búsqueda en base de datos científicos ha sido efectuada utilizándose los descriptores: Frail elderly, syndrome, phenotype, geriatric assessment y aging. Para componer el corpus literario, han sido seleccionados 66 estudios. Resultados: Se ha constatado los antecedentes y atributos (categorizados en físicos, sociodemográficos, y comportamentales/ ambientales) que integran los señales y síntomas evidenciados en el "síndrome del anciano frágil", así como los consecuentes del referido concepto. Ha procedido al análisis de las variables con destaque para las concepciones que influencian el proceso de fragilidad del anciano. Conclusión: El estudio demostró la complejidad proveniente de la génesis multifactorial del referido síndrome, resaltando las especificidades de la fragilidad del anciano. Sin embargo, se recomienda la realización de nuevas investigaciones envolviendo el fenómeno en cuestión para mejor comprensión del constructo.

Descriptores: Enfermería; Anciano Debilitado; Síndrome; Envejecimiento; Formación de Concepto. 


\section{INTRODUCTION}

Reaching older ages is considered a significant advance for humanity. As a result of social and political achievements associated with the use of new technologies, nations began a process called demographic transition. This process is characterized by a succession of events that start with the drop in mortality and fertility rates and culminate in population aging. Brazil has been experiencing this transition since 1970 and has gradually ceased to have a predominantly young population, to have an increasing number of older adults ${ }^{(1)}$.

Statistical projections suggest that in 2050 the Brazilian population will be 253 million inhabitants, only smaller than that of India, China, the United States, and Indonesia so that it will constitute the fifth largest population on the planet. In Brazil, approximately $23.8 \%$ will be elderly, which will contribute to the aging index to rise from 39.3, observed in 2010, to 152.9 in 2040. This transition has been occurring quickly and in a disorderly manner, generating a series of social changes associated with family relationships, the economic sector, and health services. All of this data unveils the need to create instruments and theoretical models that guide the health management of the elderly ${ }^{(2)}$.

From this perspective, the concept of frailty arises in the field of geriatrics and gerontology, which refers to the not optimal clinical situation, of a multi-causal and dynamic nature, linked to the life path of the elderly ${ }^{(3)}$. In the last 30 years, several attempts have been made to clarify frailty in the elderly. However, due to the multidimensional and complex nature of its genesis, there is still no literature agreement on the theoretical definition of the referred construct. Such a lack of agreement prevents the formulation of precise operational definitions that enable the identification and measurement of the phenomenon in question.

In nursing, frailty was included in the diagnosis classification of NANDA International (NANDA-I) in the 2015-2017 version, with the title "Frailty Syndrome in the Elderly." However, it is essential to note that some nursing diagnoses do not have a well-developed theoretical-conceptual basis. Thus, in practice, nurses are faced with sets of indicators that are present in various diagnoses, which creates uncertainty in the judgment and a higher chance of formulating inaccurate diagnoses. Furthermore, some elements are not consistent with the reality observed ${ }^{(4)}$.

Although there is still no agreement on this concept in the gerontological literature, there is a common understanding that fragility affects the physical, biological, psychological, and social domains. Such changes result in the imbalance of homeostatic reserves and increased vulnerability to stressors, which generates numerous harmful consequences for the life of the elderly, such as the occurrence of falls, disabilities, and limitations, institutionalization, hospitalization, and comorbidity, or even death ${ }^{(3)}$.

In this context, there is a need to clarify the meaning of the concept "Frailty Syndrome in the Elderly" and, consequently, clarify the phenomena that involve frailty and aging. Thus, we emphasize the importance of concept analysis studies to foster the construction of nursing knowledge, which, through theoreticalphilosophical foundations, enable the identification of attributes, antecedents, and consequences of relevant concepts for the development of nursing and determination of its specific field of knowledge $\mathrm{e}^{(5)}$.
It is also noteworthy that the conceptual analysis consists of an intellectual exercise that aims to synthesize and elucidate knowledge in nursing. It is necessary to use this to create concepts or when a specific construct, already introduced and defined in the literature, needs further improvement to increase its level of development, to make it more operational in theory, research and practical experience of a particular subject and improving understanding ${ }^{(5)}$.

Considering these aspects, the development of this study seeks to provide evidence to support the understanding of the frailty syndrome in the elderly, through the identification and elucidation of the various variables involved in frailty, which comprise the attributes, antecedents, and consequences of the concept in question. Therefore, the knowledge resulting from this construction will favor a theoretical basis for nurses' clinical practice to improve nursing care for this population. Besides, it will elucidate studies within the scope of academic practice that involves this phenomenon.

\section{OBJECTIVE}

To analyze, in the literature, the concept of "frailty syndrome in the elderly," according to the method proposed by Walker and Avant.

\section{METHODS}

\section{Ethical aspects}

The present study used the literature available in online databases, thus not involving human beings, so it does not need to be considered by the Ethics and Research Committee. The authors were duly cited, referenced, respecting technicalscientific knowledge according to the rules of studies based on the literature, thus respecting all ethical aspects.

\section{Theoretical-methodological framework and type of study}

This research is a descriptive study with a qualitative approach, which uses a model of concept analysis by Walker and Avant ${ }^{(6)}$. This method has eight steps: choosing a concept selection; determining the objectives and purposes of analysis; identifying all possible uses of the concept; determining the defining attributes; model case identification; identifying a model case; identifying borderline, related, contrary, invented and inappropriate cases; identifying antecedents and consequences, and defining empirical references ${ }^{(5)}$. To this end, the integrative literature reviewed is incorporated to formulate the theoretical framework of the investigation process.

The authors understand that it is necessary to analyze the basic structure of a concept, differentiating its essential attributes from less relevant ones, in order to keep it updated once the constructs change in a continuum. Thus, the clearer and more precise the concept, the better understanding, and contribution to a given area ${ }^{(5-6)}$.

\section{Methodological procedures}

\section{Data source}

In order to identify the characteristics associated with the concept, an integrative review of the literature was carried out. 
As a guiding thread for its realization, the following guiding question was formulated: "What are the antecedents, attributes, and consequences associated with frailty syndrome the literature identifies?"The analysis included original articles published online from 2012 to 2017, involving people 60 years old or older, written in Portuguese, Spanish or English, and were available in full. The study excluded review articles, opinion articles, letters to the editor, dissertations and theses, and those articles who did not subsidize a better understanding of the phenomenon in question.

To this end, the researcher herself established the search for sources indexed in scientific databases, in the database Latin American and Caribbean Health Sciences Literature (LILACS), Medical Literature Analysis and Retrieval System Online (MEDLINE), Cumulative Index to Nursing and Allied Health Literature (CINAHL), SciVerse Scopus and Base de Dados em Enfermagem (BDENF).

\section{Data collection and organization}

Data were collected in May 2017, through a structured instrument containing information on the sociodemographic characterization of the studies and on the antecedents, attributes, and consequences of the frailty syndrome in the elderly. To this end, in the search for databases, we used the following Descriptors in Health Sciences (DeCS) and its correspondents on Medical Subject Headings (MeSH): idoso fragilizado (frail elderly), síndrome (syndrome), fenótipo (phenotype), avaliação geriátrica (geriatric assessment) e envelhecimento (aging). It is noteworthy that the descriptors were combined in various possibilities in the fields "title," "abstract," and "subject," always taking into account the term "fragile elderly" as a key descriptor. We also applied these descriptors alone or together through the Boolean operator AND, to refine the findings.
After searching the database, using the terms mentioned here, 890 studies were identified, of which 738 were excluded because they did not meet the inclusion criteria. Subsequently, the 152 articles were carefully read in full, considering their adequacy and content consistency to verify antecedents, attributes, and consequents associated with the frailty syndrome in the elderly. Thus, the final sample of the literature investigated consisted of 66 studies.

\section{Data Analysis}

To the development of this synthesis, useful units of analysis were highlighted to clarify the concept studied. For this purpose, we used the thematic categorical analysis proposed by Bardin ${ }^{(7)}$, which is operationalized by the stages of pre-analysis, exploration of the material or encoding, and analysis of the results obtained and interpretation of these. In general, we identified the attributes, antecedents, and consequences of the concept studied, discussed a posteriori based on the literature.

\section{RESULTS}

The research found that most studies were developed in the area of knowledge of medicine ( $n=18 ; 54.5 \%$ ), followed by collective health $(n=6 ; 18.2 \%)$ and nutrition $(n=4 ; 12.1 \%)$. However, different subjects addressed the theme, such as physiotherapy, physical education, pharmacy, environment, physiology, and psychology, which confirms the plural approach to the phenomenon and the need to define it in nursing.

Regarding the language, there was a predominance of studies published in English (52; 78.8\%), since a large part of the sample came from scientific articles published internationally. Regarding the methodological aspects of the studies, all had a quantitative approach, prevailing the cross-sectional studies $(n=56 ; 84.8)$.

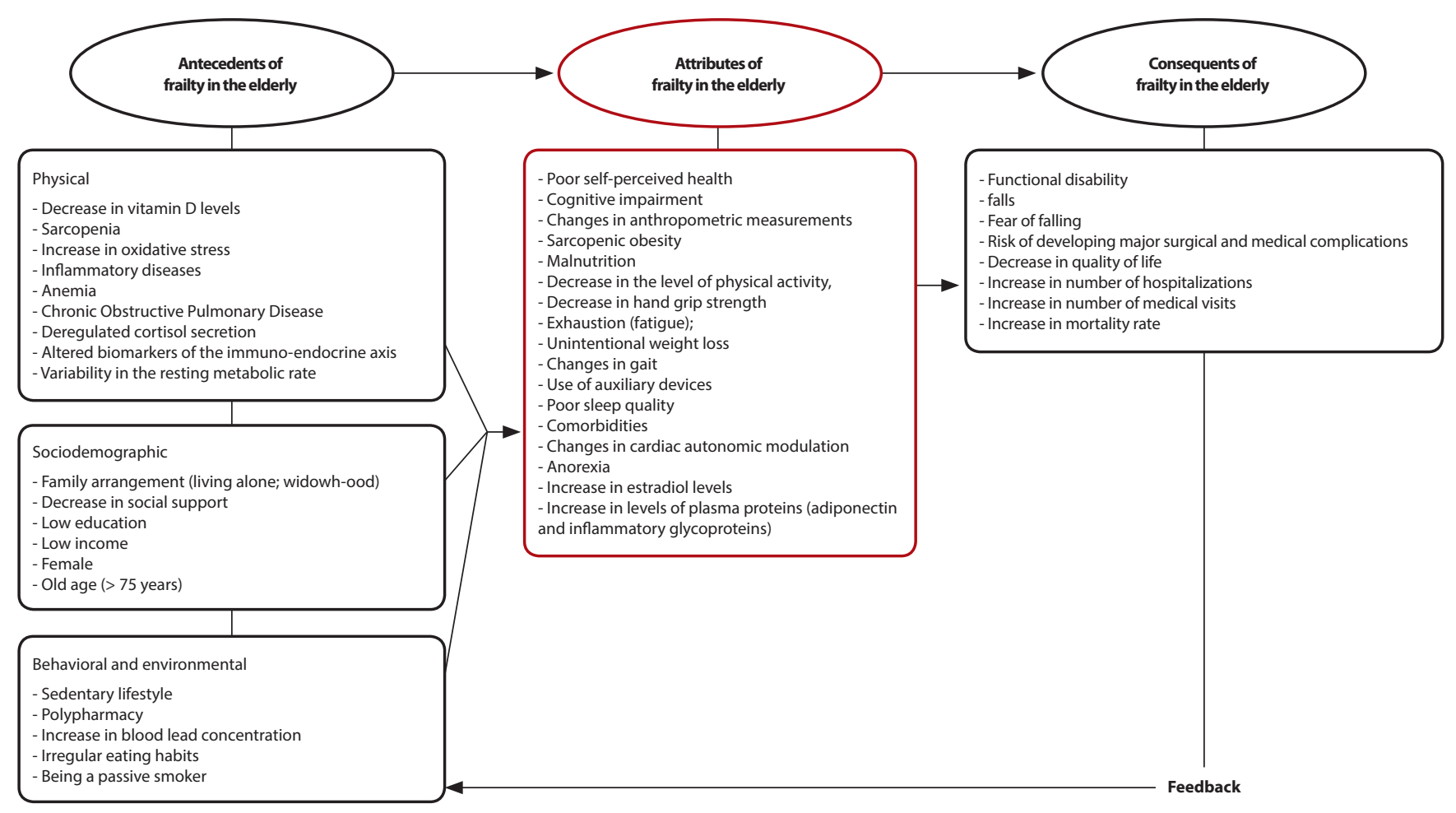

Figure 1 - Antecedents, attributes and consequences of the concept"frailty syndrome in the elderly" as demonstrated in the literature analyzed, Brazil, 2017 ( $\mathrm{n}=66$ ) 
Regarding the country of publication, Brazil prevailed $(n=28$; $42.4 \%)$, followed by the United States $(n=9 ; 13.6 \%)$, Spain $(n=5$; $7.6 \%)$, Germany $(n=4 ; 6.1 \%)$ and Japan $(n=3 ; 4.5 \%)$. Among the studies developed in Brazil, those conducted in the states of São Paulo prevailed ( $n=6 ; 21.4 \%)$ and Minas Gerais $(n=5 ; 17.8 \%$;), in addition to multicentric surveys ( $n=3 ; 9.5 \%)$. With regard to to the essential elements of the phenomenon, antecedents, attributes and consequences, these are presented in categories and subcategories of analysis, as presented in Figure 1.

\section{DISCUSSION}

\section{Antecedents of the concept "frailty syndrome in the elderly"}

The antecedents of the concept correspond to its determinants, which will be precursors of the event and will thus influence the emergence of the outcome. The results show that the frailty syndrome in the elderly is the result of several correlated circumstances, which can be grouped in physical, sociodemographic, and behavioral/ environmental antecedents. The literature identified characteristics such as decreased levels of vitamin D, sarcopenia, increased oxidative stress, family arrangement (living alone; widowhood), decreased social support, sedentary lifestyle, and polypharmacy as a cause or basis for the development of frailty in the elderly.

Regarding vitamin D decrease, low levels of 25-hydroxyvitamin $\mathrm{D}[25(\mathrm{OH}) \mathrm{D}]$ and 1.25-dihydroxy vitamin D [1.25 (OH) $2 \mathrm{D}]$ are associated with frailty. Research ${ }^{(8)}$ found that serum levels of 25 $(\mathrm{OH}) \mathrm{D}$ lower than $15 \mathrm{ng} / \mathrm{ml}$ are directly related to a higher risk of the elderly presenting exhaustion, decreased levels of physical activity and slowness, characteristics found in frailty. The decline linked to increasing age is justified by decreased efficiency in renal conversion from $25(\mathrm{OH}) \mathrm{D}$ to the active form [1.25 $(\mathrm{OH}) 2 \mathrm{D}$, which occurs even in the presence of $25(\mathrm{OH}) \mathrm{D}$ in serum at normal levels ${ }^{(8)}$.

There are several biological explanations for the association between levels lower than $25(\mathrm{OH}) \mathrm{D}$ and frailty status. Many tissues express vitamin D receptors; therefore, a physiological role for vitamin D has been proposed in various organs and organ systems, including the musculoskeletal system. In this context, low vitamin $D$ levels result in decreased muscle strength and muscle synthesis. $1.25(\mathrm{OH}) 2$ has a high affinity with the vitamin D receptor in muscle tissue and, after this binding, stimulates its actions to regulate protein synthesis. The direct influence of $1.25(\mathrm{OH}) 2$ on calcium homeostasis also affects the contractile properties of muscle cells $s^{(8)}$.

Also, in biopsies performed in individuals with vitamin D deficiency, atrophy was observed in type I and type II muscle fibers. The deficiency of this vitamin also affects phosphate transport, phospholipid metabolism, and the maintenance of bone density. These aspects are contributors to the development of frailty since it bases on the tripod of transformations linked to aging, composed of sarcopenia, neuroendocrine dysregulation, and immunological dysfunction ${ }^{(3,8)}$.

In this sense, physical activity helps to maintain muscle mass and bone replacement during the aging process, while physical inactivity has been associated with decreased quality of life, functionality, and increased frailty in the elderly. Besides, frailty factors include decreased muscle strength, changes in gait, postural instability, poor nutrition, and reduced mobility, which contribute to exercise intolerance ${ }^{(9)}$.
Another variable largely linked to frailty is oxidative stress, which is determined by the increase in lipids (malondialdehyde) and protein carbonylation, regardless of other causes of confusion, including age $\mathrm{e}^{(10)}$. The theory of free radicals in senescence argues that there is a gradual and irreversible accumulation of oxidative damage in the course of the aging process, which is responsible for damage to the functioning of body systems and the increase in the incidence of diseases. This event is the result of an increase in the resting metabolic rate, which generates a greater need for energy to maintain body homeostasis. Thus, there is an increase in mitochondrial activation, culminating in the elevation of intracellular reactive oxygen species. The high oxidative stress directly interferes with the use of proteins, leaving them even more susceptible to degradation, which will feed back this condition. Furthermore, the increase in oxidative stress activates nuclear pathways that lead to inflammation, which is also associated with frailty ${ }^{(10)}$.

In relation specifically to the family arrangement, studies show that fragility is higher in the group of elderly who live alone $e^{(11-13)}$ and those who are widowed ${ }^{(14-15)}$, emphasizing the importance of social support in the preservation of health in this population age group. The frail elderly or the ones in the process of frailty tend to have a more isolated social life, compared to those who are not going through this process. In this context, leisure activities involving family parties, trips, cultural events, and meetings are interrupted, which characterizes adaptive difficulties and difficulty in recruiting resources arising from the weakening ${ }^{(15)}$.

Study ${ }^{(16)}$ conducted with 495 elderly Chinese people observed that the level of participation in social activities had a significant influence on the probability of being fragile, so that the smaller the number of activities in which the participants were involved, the higher the probability of frailty $(O R=2.39)$. As well as social support, participation in activities, and interaction with other people are beneficial for the physical and mental well-being of the elderly. The lower the social interaction, the higher the isolation, and the occurrence of depression, which also predisposes to frailty ${ }^{(16)}$.

Regarding polypharmacy, studies ${ }^{(12,17-20)}$ indicate a statistically relevant association between the use of five or more medications and frailty. Also, for each additional drug consumed per day, the probability of being fragile increases by $30 \%(21)$. The use of various drugs, associated with the physiological decline for biotransformation and excretion of these substances, predisposes the elderly to a higher occurrence of adverse reactions and drug interactions that can result in postural hypotension, sedation, falls, and other injuries ${ }^{(17)}$. In addition, results found directly links polypharmacy to a high number of pathologies or their worsening, which also influence the frailty in the elderly ${ }^{(22)}$.

\section{Attributes of the concept "frailty syndrome in the elderly"}

The attributes express the properties of the concept. That is, they are elements that describe specific characteristics of a particular construct. It is possible to reveal these attributes as clinical manifestations, or the signs and symptoms, which allow the establishment of differential diagnoses. After analyzing the investigated literature, the following attributes of the concept in question were observed, among other aspects: poor self-perceived health, cognitive impairment, changes in anthropometric measurements, and sarcopenic obesity. 
Concerning self-perceived health, a study ${ }^{(19)}$ conducted with elderly Brazilians found that individuals in pre-frailty and frailty conditions had $67 \%$ and $82 \%$ more chances, respectively, for poor health perception. Other studies have shown an association between frailty and negative self-perception of health ${ }^{(13,20,22-25)}$, including oral health ${ }^{(21)}$, which may be strongly related to the increase in the number of morbidities, the higher susceptibility to adverse events and the disappointments and failures accumulated throughout life, common to the elderly classified as fragile ${ }^{(19)}$. This hypothesis is supported by the theory that suggests a relationship between resilience and frailty syndrome ${ }^{(24-25)}$.

Corroborating this, a study ${ }^{(21)}$ carried out with 838 Mexicanelderly people showed that frail older adults tended not to use dental services during the previous year and that the probability of being fragile was 2.2 times higher in those who considered their oral health to be poor. That is because, in some cultures, the elderly have the idea that the decline in oral health is inherent to the aging process and that its improvement is not possible. Also, home restrictions, decreased mobility, and weakness observed in these individuals are barriers to not looking for dental care. Thus, it is worth mentioning that such a weakening of oral health affects the choice of food, the chewing mechanism, the stereotype, speech, social interaction, in addition to increasing the markers of inflammation, which can lead to impairment of the general health status and result in frailty ${ }^{(21)}$.

Concerning cognitive impairment, a study ${ }^{(18)}$ found an odds ratio up to seven times higher in frail elderly to present cognitive impairment when compared to robust individuals. Another survey ${ }^{(26)}$, carried out with 383 elderly Brazilians, identified that the elderly in frailty condition had significantly lower scores in the Mini-Mental State Examination (MMSE) and the subdomains time orientation, immediate memory, and commands. In accordance with these findings, an investigation carried out with 737 elderly Brazilians found a statistically significant association between low cognitive performance and frailty ${ }^{(27)}$. Some authors ${ }^{(18,28)}$ point out such harm as one of the causes for the onset of frailty and even suggest the inclusion of this variable in its definition; others ${ }^{(22,27)}$ report cognitive impairment as an indicator of frailty.

Several shared biological and behavioral mechanisms can cause impairment in cognitive functions. For example, oxidative stress and inflammation, in addition to lifestyle (such as stress and chronic illnesses), can accelerate telomere shortening, which leads to cell death. In the brain, this may be associated with dementia and, consequently, with a more significant cognitive decline. Another mechanism linked to the decrease in cognitive functioning is the decline in cognitive and physiological reserves, typical of increasing age ${ }^{(10,13,18,20,22,26,29)}$.

In line with these findings, a study ${ }^{(28)}$ conducted with 273 Japanese older adults found, in those classified as fragile, significantly lower rates in the Mini-Mental State Examination (MMSE) and the Scenery Picture Memory Test (SPMT). The MMSE evaluates the global cognitive function through five areas: orientation, registration, attention and calculation, memory, and language. SPMT is a simple memory test that assesses visual memory combined with verbal responses ${ }^{(28)}$.

Another dimension that has been correlated in the gerontological literature with the frailty syndrome categorizes as changes in anthropometric measurements, which reflect not only the morphological changes resulting from senescence but also variations resulting from illnesses. Study ${ }^{(30)}$ carried out with 521 elderly Brazilians found that the frail elderly showed lower measurements of height, knee height, the circumference of the forearm, and calf, which reflect a loss of muscle mass and decreased physical constitution. The same investigation indicates an increase in the representative measures of the distribution of body fat (taper index, sagittal index, hip circumference measurements, higher waist/height ratio, waist/thigh, and waist/calf) in women in frailty condition when compared to the robust ${ }^{(30)}$. Similarly, research that investigated cardiovascular risk factors and the frailty syndrome found greater waist circumference in the group of frail elderly compared to that of non-frail elderly ${ }^{(31)}$.

Such changes reverberate in an increased risk of cardiovascular diseases, metabolic disorders, central obesity, and sarcopenia. The increase in adipose tissue is related to the increased production of cytokines and pro-inflammatory mediators, such as interleukin- 6 and C-reactive protein, which leads to a state of chronic inflammation present in the frailty syndrome. In this context, there is an association between higher values of body mass index and frailty ${ }^{(9,32)}$. However, there is also an increase in adipose tissue with advancing age, regardless of the referred index, known as sarcopenic obesity, in which there is a greater deposit of visceral fat and especially an increase in the fatty infiltration into the muscles. Therefore, the body mass index does not seem to be the best indicator of adiposity because it demonstrates that both fat mass and lean body mass contribute to poor health in the elderly ${ }^{(23)}$.

On the other hand, a study carried out in Turkey showed that $61 \%$ of the elderly who were at risk for malnutrition were frail. Both frailty and malnutrition have overlapping pathogens, such as decreased muscle mass, anorexia, low intake of vitamins and fluids, poor self-perceived health, and the presence of comorbidity, which in several times result in increased disabilities and feedback the fragility cycle ${ }^{(17)}$.

Also, a significant number of frail elderly are unable to eat enough food to meet their vital energy and nutrient needs. This difficulty results in weight loss, sarcopenia, decreased resistance, and anorexia of aging. Anorexia in senescence has as a triggering factor the reduction of the natural impulse to eat food, influenced by decreased chemosensory functions, impaired psychological functions, changes in oral health, environmental changes, and decreased secretions of the hormones that regulate appetite ${ }^{(17)}$. In this context, a study carried out with 4,417 Japanese elderly found a significant association between frailty and anorexia, especially in the components of the phenotype of slowness, exhaustion, and weight loss ${ }^{(33)}$.

\section{Consequences related to the "frailty syndrome in the elderly" concept}

The consequences of the concept show the outcomes that occur after the construction arises. This study found functional disability and falls to be the main consequences of frailty syndrome in the elderly.

Fragility and functional incapacity, represented for the limitation of activities, are considered distinct entities with some degree of overlapping. In this context, the incapacity represents one of the outcomes of the well-delimited fragility in the national and 
international literature, which points to elderly dependence in basic $^{(12-13,20-21,23-25,34)}$ and instrumental ${ }^{(12,14,18-19,22,25,27-29)}$ activities and also in advanced activities of daily life ${ }^{(14)}$.

This finding occurs due to the attributes of the frailty syndrome to also constitutes the origin of functional incapacity ${ }^{(24-25)}$. Corroborating this, a prospective study ${ }^{(3)}$ conducted with 2,420 elderly observed that those classified as fragile had a more significant decline in basic activities of daily living when compared to pre-frail elderly.

Another prospective investigation ${ }^{(29)}$, carried out in Italy, involved 2,581 older adults and identified a chance 1.32 times greater and statistically significant, after a three-year follow-up, for the development of disabilities in individuals identified as fragile at the beginning of the investigation. This same study pointed out that $39.3 \%$ of fragile individuals did not have a disability. Another survey of Colombian older adults showed that, among those classified as fragile, only $10 \%$ did not have a disability ${ }^{(22)}$. These data confirm an overlap, but no agreement on the co-occurrence between these conditions.

With regard to the history of falls, the literature shows that frail older adults show a tendency to suffer a higher number of falls, when compared to pre-frail and non-frail elderly ${ }^{(11,13-14,17,22,25)}$. The explanation for this association is not yet properly clarified; however the aging process causes a decrease in visual acuity, body balance, mobility, and all physical aspects, variables that are directly related to the increase in the occurrence of falls. All this decline associated with the frailty syndrome will cause an increase in the number of falls since these two outcomes have components in common - for example, sarcopenia ${ }^{(11)}$. However, it is worth noting that these variables have a bidirectional relationship so that frailty can influence the increase in the number of falls, and the occurrence of falls can contribute to the development of frailty ${ }^{(35)}$.

\section{Study Limitations}

This conceptual analysis comprised only studies available electronically, in specific databases, and with a time frame, which may have caused the exclusion of research contemplating other perspectives of frailty in senescence. Although there is no consensus in the literature regarding the frailty syndrome in the elderly, frailty is widely discussed and investigated in several areas. It has a vast collection of scientific productions, but which do not always clearly express the antecedents, attributes, and consequences of the concept.

\section{Contributions to the nursing field}

As for contributions to the nursing area, the deepening of the phenomenon studied, which corresponds to the title of the nursing diagnosis of NANDA-I taxonomy ${ }^{(4)}$. In this regard, it is known that the beginning of the diagnostic validation process is operationalized through concept analysis to identifying whether the list of diagnostic indicators presented in the taxonomy is based on the literature. Such a process ensures the uniform use of the concept in the area of interest, besides fostering the development of essential concepts for professional and scientific growth of nursing. Specifically, on the formulation of diagnosis, the concept analysis presented here will contribute to the theoretical basis that provides support to critical thinking and diagnostic reasoning of nurses who experience care for the frail elderly.

\section{FINAL CONSIDERATIONS}

The analysis of the concept of "frailty syndrome in the elderly" made it possible to approach the theme based on the identification of the antecedents, attributes, and consequences of the investigated problem. Given the considerations now exposed, the analyzed articles reveal the national and international panorama regarding the concept of "frailty syndrome in the elderly."Through this panorama, we confirmed the complexity arising from the multifactorial genesis of the phenomenon under study. It is also noteworthy that, despite the wide use of the term frailty, there is no consensus in the literature on it, thus evidencing divergent nonspecific definitions that do not adequately subsidize nursing care for the frail elderly.

The frailty syndrome in the elderly is characterized by its multidimensionality, involving the decline of physical, biological, social, and psychological domains, which damage homeostatic reserves and, therefore, increase vulnerability to stressors. Therefore, we emphasize the need for more in-depth studies on the understanding of the concept, especially regarding the determinant aspects for the emergence or not of the syndrome, thus allowing its clarification, which will provide a basis for the formulation of health actions in the face of real needs of the frail elderly.

Given the above, we conclude that concept analysis studies are of paramount importance for the refinement of these, as they will provide the most accurate clinical reasoning and, consequently, more effective therapeutic plans. Thus, the results obtained through this research reveal substantial subsidies for planning and implementing interventions that improve nursing care, living conditions, and the well-being of the elderly in the process of frailty.

\section{FUNDING}

This work was carried out during the PhD course in Nursing, with the financial support of the Coordination of Superior Level Staff Improvement (CAPES).

\section{REFERENCES}

1. Myrrha LJD, Turra CM, Wajnman S. A contribuição dos nascimentos e óbitos para o envelhecimento populacional no Brasil, 1950 a 2100. Rev Latinoamericana Poblaciós [Internet]. 2017 [cited 2018 Aug 03];11(20):37-54. Available from: https://www.researchgate.net/ publication/319434034_A_contribuicao_dos_nascimentos_e_obitos_para_o_envelhecimento_populacional_no_Brasil_1950_a_2100

2. Miranda GMD, Mendes ACG, Silva ALA. O envelhecimento populacional brasileiro: desafios e consequências sociais atuais e futuras. Rev Bras Geriatr Gerontol. 2016;19(3):507-19. doi: 10.1590/1809-98232016019.150140 
3. Veld LPMO, Ament BHL, Rossum EV, Kempen GIJM, Vet HCW, Hajema K, et al. Can resources moderate the impact of levels of frailty on adverse outcomes among (pre-) frail older people? a longitudinal study. BMC Geriatrics [Internet]. 2017 [cited 2018 Aug 04];17(185). Available from: https://www.ncbi.nlm.nih.gov/pmc/articles/PMC5561574/

4. Diagnósticos de enfermagem da NANDA-I: definições e classificação 2018-2020. 11 ed. Porto Alegre: Artmed; 2018.

5. Sousa LMM, Firmino CF, Carteiro DMH, Frade F, Marques JM, Antunes AV. Análise de conceito: conceitos, métodos e aplicações em enfermagem. Revista investigação em enfermagem [Internet]. 2018 [cited 2019 Aug 11]:9-19. Available from:https://www.researchgate.net/ publication/330205622_ANALISE_DE_CONCEITO_CONCEITOS_METODOS_E_APLICACOES_EM_ENFERMAGEM

6. Walker LO, Avant KC. Strategies for theory construction in nursing. 6 ed. Upper Saddle River: Pearson Prentice Hall; 2010.

7. Bardin L. Análise de conteúdo. São Paulo: Edições 70; 2011.

8. Pabst G, Zimmermann AK, Huth C, Koenig W, Ludwig T, Zierer A, et al. Association of low 25-hydroxyvitamin d levels with the frailty syndrome in an aged population: results from the kora-age Augsburg Study. J Nutr Health Aging [Internet].2015 [cited 2018 Aug 11];19(3):258 -64. Available from: https://www.ncbi.nlm.nih.gov/pubmed/25732209

9. Schwenk M, Mohler J, Wendel C, D'Huyvetter K, Fain M, Taylor-Piliae R, et al. Wearable sensor-based in-home assessment of gait, balance, and physical activity for discrimination of frailty status: baseline results of the Arizona Frailty Cohort Study. Gerontology [Internet]. 2015 [cited 2018 Aug 11];61(3):258-67. Available from: https://www.ncbi.nlm.nih.gov/pmc/articles/PMC4452118/

10. Ingles M, Gambini J, Carnicero JA, Garcia-Garcia FJ, Rodriguez-Manas L, Olaso-Gonzalez G, et al. Oxidative stress is related to frailty, not to age or sex, in a geriatric population: lipid and protein oxidation as biomarkers of frailty. JAGS [Internet]. 2014 [cited 2018 Aug 12];62:1324-8. Available from: https://www.ncbi.nlm.nih.gov/pubmed/24962132

11. Santos PHS, Fernandes MH, Casotti CA, Coqueiro RS, Carneiro JAO. Perfil de fragilidade e fatores associados em idosos cadastrados em uma Unidade de Saúde da Família. Ciên Saúde Coletiva [Internet]. 2015 [cited 2018 Aug 12];20(6):1917-24. Available from: http://www.scielo.br/ pdf/csc/v20n6/1413-8123-csc-20-06-1917.pdf

12. Bollwein J, Diekmann R, Kaiser MJ, Bauer JM, Uter W, Sieber CC, et al. Dietary Quality Is Related to Frailty in Community-Dwelling Older Adults. J Gerontol A Biol Sci Med Sci [Internet]. 2013 [cited 2018 Aug 13];68(4):483-9. Available from: https://www.ncbi.nlm.nih.gov/ pubmed/23064817

13. Moreira VG, Lourenço RA. Prevalence and factors associated with frailty in an older population from the city of Rio de Janeiro, Brazil: the FIBRA-RJ Study. Clinics [Internet]. 2013;68(7):979-85. doi: 10.6061/clinics/2013(07)15

14. Silva SLA, Neri AL, Ferrioli E, Lourenço RA, Dias RC. Fenótipo de fragilidade: influência de cada item na determinação da fragilidade em idosos comunitários - Rede Fibra. Ciên Saúde Coletiva [Internet]. 2016 [cited 2018 Aug 15];21(11):3483-92. Available from: http://www. scielo.br/pdf/csc/v21n11/1413-8123-csc-21-11-3483.pdf

15. Nascimento PPP, Batistoni SST, Neri AL. Frailty and depressive symptoms in older adults: data from the FIBRA study - UNICAMP. Psicol Reflex Crít [Internet]. 2016 [cited 2018 Aug 15];29(16):1-11. doi: 10.1186/s41155-016-0033-9

16. Chen LJ, Chen CY, Lue BH, Tseng MY, Wu SC. Prevalence and Associated Factors of Frailty Among Elderly People in Taiwan. Int J Gerontol. 2014;14-9. doi: 10.1093/gerona/glx098

17. Eyigor S, Kutsal YG, Duran E, Huner B, Paker N, Durmus B, et al. Frailty prevalence and related factors in the older adult-Frail TURK Project. AGE [Internet]. 2015 [cited 2018 aug 15];37(50):1-13. Available from: https://www.ncbi.nlm.nih.gov/pubmed/25948502

18. Kulmala J, Nykänen I, Mänty M, Hartikainen S. Association between Frailty and Dementia: a Population-Based Study. Gerontology [Internet]. 2014 [cited 2018 Aug 16];60:16-21. Available from: https://www.ncbi.nlm.nih.gov/pubmed/23970189

19. Pegorari MS, Tavares DMS. Identificar a ocorrência e os fatores associados às condições de pré-fragilidade e fragilidade em idosos. Rev Latino-Am Enfermagem [Internet]. 2014 [cited 2018 Aug 18];22(5):874-82. Available from: http://www.scielo.br/pdf/rlae/v22n5/pt_01041169-rlae-22-05-00874.pdf

20. Castell MV, Sánchez M, Julián R, Queipo R, Martín S, Otero A. Frailty prevalence and slow walking speed in persons age 65 and older: implications for primary care. BMC Fam Pract [Internet]. 2013 [cited 2018 Aug 19];14(86):1-9. Available from: https://www.ncbi.nlm.nih.gov/ pubmed/23782891

21. Castrejón-Pérez RC, Borges-Váñez SA, Gutiérrez-Robledo LM, Ávila-Funes JA. Oral health conditions and frailty in Mexican communitydwelling elderly: a cross sectional analysis. BMC Public Health [Internet]. 2012 [cited 2018 Aug 19];12:773-85. Available from: https://www. ncbi.nlm.nih.gov/pubmed/22971075

22. Curcio CL, Henao GM, Gomez F. Frailty among rural elderly adults. BMC Geriatr [Internet]. 2014 [cited 2018 Aug 22];14(2):1 - 9. Available from: https://www.ncbi.nlm.nih.gov/pubmed/24405584

23. Ricci NA, Pessoa GS, Ferriolli E, Dias RC, Perracini MR. Frailty and cardiovascular risk in community-dwelling elderly: a population-based study. Clin Intervent Aging [Internet]. 2014 [cited 2018 Aug 23];9:1677-85. Available from: https://www.ncbi.nlm.nih.gov/pubmed/25336932

24. Reis Jr WM, Carneiro JÁ, Coqueiro ORS, Santos KT, Fernandes M.H. Pré-fragilidade e fragilidade de idosos residentes em município com baixo Índice de Desenvolvimento Humano. Rev Latino-Am Enfermagem [Internet]. 2014 [cited 2018 Aug 23];22(4):654-61. Available from: http://www.scielo.br/pdf/rlae/v22n4/pt_0104-1169-rlae-22-04-00654.pdf

25. Sousa ACPA, Dias RC, Maciel ACC, Guerra RO. Frailty syndrome and associated factors in community-dwelling elderly in Northeast Brazil. Arch Gerontol Geriatr [Internet]. 2012 [cited 2018 Aug 24];54:95- 101. Available from: https://www.ncbi.nlm.nih.gov/pubmed/21930311 
26. Macuco CRM, Batistoni SST, Lopes A, Cachioni M, Falcão DVS, Neri AL, et al. Mini-Mental State Examination performance in frail, pre-frail, and non-frail community dwelling older adults in Ermelino Matarazzo, São Paulo, Brazil. Int Psychogeriatr. 2012;24(11):1725-31. doi: 10.1017/ S1041610212000907

27. Faria CA, Lourenço RA, Ribeiro PCC, Lopes CS. Desempenho cognitivo e fragilidade em idosos clientes de operadora de saúde. Rev Saúde Pública [Internet]. 2013 [cited 2018 Aug 25];47(5):923-30. Available from: http://www.scielo.br/pdf/rsp/v47n5/0034-8910-rsp-47-05-0923.pdf

28. Nishiguchi S, Yamada M, Fukutani N, Adachi D, Tashiro Y, Hotta T, et al. Differential association of frailty with cognitive decline and sarcopenia in community-dwelling Older Adults. JAMDA [Internet]. 2015 [cited 2018 Aug 25];16:120 - 4. Available from: https://www.ncbi. nlm.nih.gov/pubmed/25244957

29. Solfrizzi V, Scafato E, Frisardi V, Sancarlo D, Seripa D, Logroscino G, et al. Frailty syndrome and all-cause mortality in demented patients: the Italian Longitudinal Study on Aging. AGE [Internet]. 2012 [cited 2018 Aug 25];34:507-17. Available from: https://www.ncbi.nlm.nih.gov/ pmc/articles/PMC3312634/

30. Closs VE, Rosemberg LS, Ettrich BG, Gomes I, Schwanke CHA. Medidas antropométricas em idosos assistidos na atenção básica e sua associação com gênero, idade e síndrome da fragilidade: dados do EMI-SUS. Sci Med [Internet]. 2015 [cited 2018 Aug 26];25(3). Available from: http://pesquisa.bvs.br/ripsa/resource/pt/biblio-832156

31. Bastos-Barbosa RG, Ferriolli E, Coelho EB, Moriguti JC, Nobre F, Lima NKC. Association of frailty syndrome in the elderly with higher blood pressure and other cardiovascular risk factors. Am J Hypertension [Internet]. 2012 [cited 2018 Aug 27];25(11):1156-61. Available from: https://www.ncbi.nlm.nih.gov/pubmed/22810844

32. Gharacholou SM, Roger VL, Lennon RJ, Rihal CS, Sloan JA, Spertus JA, et al. Comparison of Frail Patients vs Non-Frail Patients $\geq 65$ Years of Age Undergoing Percutaneous Coronary Intervention. Am J Cardiol [Internet]. 2012 [cited 2018 Aug 27];109(11):1569-75. Available from: https://www.ncbi.nlm.nih.gov/pmc/articles/PMC5018988/

33. Tsutsumimotoa K, Doia T, Makizakoa H, Hottaa R, Nakakuboa S, Makinoa K, et al. The association between anorexia of aging and physical frailty: results from the national center for geriatrics and gerontology's studyof geriatric syndromes. Maturitas [Internet]. 2017 [cited 2018 Aug 29];97:32-37. Available from: https://www.ncbi.nlm.nih.gov/pubmed/28159059

34. Marchiori GF, Tavares DMS. Mudanças nas condições de fragilidade e componentes do fenótipo em idosos após hospitalização. Rev LatinoAm Enfermagem [Internet]. 2017 [cited 2018 Aug 30];25:e2905. doi: 10.1590/1518-8345.1417.2905

35. Lenardt MH, Carneiro NHK, Binotto MA, Setoguchi LS, Cechinel C. Relação entre fragilidade física e características sociodemográficas e clínicas de idosos. Esc Anna Nery [Internet]. 2015 [cited 2018 Aug 30];19(4). Available from: http://www.scielo.br/pdf/ean/v19n4/1414-8145ean-19-04-0585.pdf 